\title{
EXTRAOVARIAN EFFECT OF PROLACTIN ON THE TRAUMATIZED UTERUS IN THE RAT
}

\author{
M. M. JOSEPH AND H. B. MUBAKO \\ Department of Biology, University of Zambia, \\ P.O. Box 2379, Lusaka, Zambia
}

(Received 14th April 1975)

Intrauterine devices are reported to have uterine growth-promoting action (Gregorie \& Ansbacher, 1972; Lau et al., 1974). Moreover, their presence alters the sensitivity of the uterus to oestrogens (Brown-Grant, 1969; Joshi, 1970). Kennedy \& Armstrong (1972) have demonstrated that prolactin, besides its indirect effect via the stimulation of progesterone secretion, acted with oestrogen to cause relaxation of the cervix in rats. The present study was carried out to determine the effects of trauma and prolactin treatment on the uterine responses of ovariectomized rats.

Cyclic 7- to 8-week-old virgin albino rats, weighing 150-170 g, maintained at constant temperature $\left(22 \pm 2^{\circ} \mathrm{C}\right)$ and artificial lighting from 08.00 to 20.00 hours, were used. They had free access to tap water and diet pellets. Bilateral ovariectomy was performed on 22 rats under ether anaesthesia. Eleven of the animals were also subjected to uterine trauma by sewing three cotton-thread (No. 50) loops into each uterine horn. Commencing 1 day after surgery, ovine prolactin $(200 \mu \mathrm{g}$ in $0.1 \mathrm{ml} 0.9 \% \mathrm{NaCl} /$ injection: NIH-P-S10) or $0.1 \mathrm{ml}$ solvent was given subcutaneously once daily to all animals at 12.00 hours for 6 consecutive days. The treatment groups are shown in Table 1. Twenty-four hours after

Table 1. The effect of prolactin on the uterine response of ovariectomized rats

\begin{tabular}{lccc}
\hline \multicolumn{1}{c}{ Treatment } & $\begin{array}{c}\text { Wet wt of } \\
\text { uterus }\end{array}$ & $\begin{array}{c}\text { Wt of luminal } \\
\text { fluid }\end{array}$ & $\begin{array}{c}\text { Dry wt of } \\
\text { uterus }\end{array}$ \\
\hline Ovariectomy+trauma +prolactin (6) & $241 \cdot 04 \pm 16 \cdot 74$ & $37 \cdot 60 \pm 3 \cdot 58$ & $72 \cdot 04 \pm 5 \cdot 91$ \\
Ovariectomy +trauma (5) & $160 \cdot 56 \pm 13 \cdot 22$ & $24 \cdot 32 \pm 3 \cdot 84$ & $46 \cdot 46 \pm 2 \cdot 00$ \\
Ovariectomy +prolactin (6) & $115 \cdot 35 \pm 22 \cdot 13$ & $12 \cdot 65 \pm 1 \cdot 87$ & $32 \cdot 33 \pm 4 \cdot 32$ \\
Ovariectomy (5) & $94 \cdot 80 \pm 15 \cdot 17$ & $9 \cdot 63 \pm 1 \cdot 30$ & $24 \cdot 94 \pm 2 \cdot 51$
\end{tabular}

\footnotetext{
Values are Means \pm S.E.M. expressed as $\mathrm{mg} / 100 \mathrm{~g}$ body wt. Figures in parentheses indicate number of animals.
}

the last injection the animals were killed by decapitation. The uterus of each animal was dissected out, and weighed on a Metler balance to the nearest mg after excision of the threads. The intraluminal fluid was then expressed and uterus reweighed (wet weight) to yield the weight of intraluminal fluid. The tissues were dehydrated to constant weight in a hot-air oven at $80^{\circ} \mathrm{G}$. Statistical significance of the data was determined by Student's $t$ test. 
The results are summarized in Table 1. Trauma was found to induce marked hypertrophy of uterine tissue as indicated by increased wet as well as dry weights $(P<0.01)$. The uterine hypertrophy in the traumatized animals receiving prolactin was significantly greater $(P<0.01)$ than in those of the other groups. The uteri of the non-traumatized rats receiving prolactin did not show any significant change from those of controls. Thus trauma was found to increase the uterine sensitivity to prolactin in the absence of the ovaries. Neither uterine ballooning nor growth of deciduomata was noted in any of the animals.

The increase in uterine weight in the presence of intrauterine devices might be the result of increased prostaglandin $\mathrm{F}$ production in the uterine horns. However, indomethacin, an inhibitor of prostaglandin biosynthesis, could not abolish this increase in uterine weight (Lau et al., 1974). Progesterone and oestrogen are reported to have a stimulatory effect on uterine prostaglandin F production in guinea-pigs (Blatchley et al., 1971) and mice (Saksena \& Lau, 1973). Even though the mode of action of prolactin cannot be determined from the present experiment, it is possible that either prolactin sensitized the traumatized uterus to produce an increased amount of prostaglandins, or prolactin and prostaglandins acted synergistically to give a more pronounced hypertrophy of the uterine tissue.

The ovine prolactin (NIH-P-S10) was a gift of the Endocrinology Study Section of the National Institutes of Health, U.S.A. The work was supported by a Grant from the Research and Higher Degree Committee of University of Zambia.

\section{REFERENCES}

Blatchley, F.R., Donovan, B.T., Poyser, N.L., Horton, E.W., Thompson, C.J. \& Los, M. (1971) Identification of prostaglandin $F_{2 \alpha}$ in the utero-ovarian blood of guinea pigs after treatment with oestrogen. Nature, Lond. 230, 243-244.

Brown-Grant, K. (1969) Effects of an IUCD on endometrial response to steroid hormones in the rat. 7. Reprod. Fert. 18, 475-480.

Gregorie, A.T. \& ANSBAcher, R. (1972) The effect of an intrauterine device on uterine weight and water content and on genital tract glycogen of cycling, ovariectomized, pseudopregnant or oestrogen-treated hamsters. F. Reprod. Fert. 31, 341-345.

Joshi, S.G. (1970) Effect of a foreign body on responses of the uterus to estrogen in ovariectomized rats. Contraception 2, 137-148.

KenNedy, T.G. \& ARMSTRong, D.T. (1972) Extraovarian action of prolactin in regulation of uterine lumen fluid accumulation in rats. Endocrinology 90, 1503-1509.

Lau, I.F., Saksena, S.K. \& Chang, M.C. (1974) Prostaglandin F in the uterine horns of mice with intrauterine devices. 7. Reprod. Fert. 37, 429-432.

SAKSENA, S.K. \& LAU, I.F. (1973) Effect of exogenous estradiol and progesterone on the uterine tissue levels of prostaglandin $\mathrm{F}_{2 \alpha}\left(\mathrm{PGF}_{2 \alpha}\right)$ in ovariectomized mice. Prostaglandins 3, 317-322. 